\title{
Factors influencing survival and mode of death in severe chronic ischaemic cardiac failure
}

\author{
DAVID R GLOVER, WILLIAM A LITTLER \\ From the Department of Cardiovascular Medicine, University of Birmingham, East Birmingham Hospital, \\ Birmingham
}

SUMMARY An evaluation of factors which may influence survival and mode of death was conducted over a three year period in a consecutive series of 50 patients with severe chronic ischaemic cardiac failure for more than three months. At the initial assessment all patients were already receiving intensive medical treatment. During follow up four patients successfully underwent cardiac surgery and medical treatment was modified in most patients, with four patients receiving antiarrhythmic drugs. Twenty six patients died: 17 suddenly within one hour of onset of symptoms and nine of progressive cardiac failure. The mortality by one year was $26 \%$ and by two years it was $62 \%$. Comparison of those who survived with those who died within one year of follow up showed that a very low left ventricular ejection fraction, severe ventricular arrhythmias, the presence of gallop rhythm, and New York Heart Association class IV were the variables that predicted mortality. By two years left ventricular ejection fraction, ventricular arrhythmias, and pulmonary capillary wedge pressure were the variables that were significantly different in survivors and patients who died. No differences were found in any of the recorded variables between those who died suddenly and those who did not.

Thus in patients with chronic ischaemic cardiac failure determination of the left ventricular ejection fraction and the severity of ventricular arrhythmia on the ambulatory electrocardiogram are the best ways to predict prognosis. The presence of gallop rhythm and New York Heart Association class IV status predict early death.

Severe chronic cardiac failure occurring as a consequence of ischaemic heart disease is common. Many studies in the United States have documented the course of the disease ${ }^{1-3}$ and have described certain indicators of outcome..$^{4-6}$ The Framingham Study emphasised that the prognosis was little better than for cancer in general. ${ }^{7}$ Surprisingly there is no major United Kingdom contribution to published reports on this topic.

In the past decade there has been considerable interest in new drug treatments for severe cardiac failure, especially vasodilators ${ }^{389}$ and inotropes, ${ }^{10-12}$ with considerable attention being paid to the influence of these drugs on haemodynamic

Requests for reprints to Dr David R Glover, Medical Department, Merck Sharp and Dohme Limited, Hertford Road, Hoddesdon, Hertfordshire EN11 9BU.

Accepted for publication 6 October 1986 variables and exercise tolerance. Despite these newer drugs the mortality from the syndrome remains high and the prognosis remains poor. An editorial by Wilson reviewed the subject and advocated optimisation of medical treatment by the physician, and education of the patient's family in the recognition of the signs of sustained ventricular tachycardia and training in cardiopulmonary resuscitation because at least half of such patients die suddenly. ${ }^{13}$

We describe our experience gained over three years at a major referral centre for cardiology patients, describe the course of the disease, and identify factors that influence survival and mode of death in patients with chronic ischaemic cardiac failure.

\section{Patients and methods}

INCLUSION CRITERIA

Patients were recruited from routine outpatient practice. Fifty consecutive patients were entered 
according to the following criteria: (a) age $<70$ years; (b) proven diagnosis of ischaemic heart disease, either documented previous myocardial infarction and/or presence of significant ( $>50 \%$ ) narrowing of one or more major coronary arteries demonstrated at coronary angiography; (c) left ventricular failure of more than three months' duration, characterised by any or several of the followingdyspnoea and/or fatigue or exertion, paroxysmal nocturnal dyspnoea, peripheral oedema, gallop rhythm, pulmonary congestion, and documented by reduced left ventricular ejection fraction measured either by cineangiography or by radionuclide angiography or by $M$ mode echocardiography and requiring treatment with diuretics with or without digoxin and/or drugs with vasodilator activity.

Patients were specifically excluded if there was evidence of significant valvar heart disease or chronic obstructive airways disease. Inpatients were not included but were identified and included in the study if they were eligible when they attended as outpatients.

\section{CLINICAL ASSESSMENT AND FOLLOW UP}

The initial clinical assessment included a review of all previous investigations. The date of initiation of diuretic treatment was taken as the date of onset of left ventricular failure. All current medication at the time of assessment was noted, and further investigations to confirm and elucidate the diagnosis of left ventricular failure as a consequence of coronary artery disease were performed within six weeks. The New York Heart Association functional classification was assessed.

All patients were followed up regularly and medical treatment was changed or operation performed when appropriate. Details of deaths were obtained from hospital inpatient case records, general practitioners' records, and relatives' accounts. The date, cause, and mode of death was ascertained; for the purpose of this study death was defined as sudden if it occurred within one hour of onset of symptoms and/or was unexpected. The minimum follow up for survivors was 15 months.

\section{STATISTICAL ANALYSIS}

Survivors and deaths were compared at one and two years by an unpaired Student's $t$ test or a $\chi^{2}$ test as appropriate. Sudden and non-sudden deaths were compared by the same criteria. A p value of $<0.05$ was taken as significant.

\section{Results}

PATIENT CHARACTERISTICS

\section{Age and sex}

There were $40(80 \%)$ men and $10(20 \%)$ women (mean (SD) age 56.9 (6.7) years, range 39-70).
Medical history

The mean (SD) duration of left ventricular failure was 16.7 (13.6) months (range 3-65 months) Ischaemic heart disease was confirmed by documen $-\frac{}{0}$ ted previous myocardial infarction in $43(86 \%)$ patients and by coronary angiography in the remain- $\Phi$ ing seven (14\%) patients who had not had a myo cardial infarction. The number of myocardia $\mathrm{P}^{\text {? }}$ infarctions was zero in seven patients, one in $21 \vec{\circ}$ patients, two in 13 patients, three in eight patients, and $>3$ in one patient. Coronary angiography waso performed in 42 patients: single vessel disease was? found in three patients, double vessel disease in twoir patients, and triple vessel disease in 37 patients Eleven $(22 \%)$ patients had a history of hypertension(blood pressure $>160 / 95 \mathrm{~mm} \mathrm{Hg}$ ) that required treatment. None of the patients was hypertensive af assessment. Seven (14\%) patients had diabetesmellitus. Previous pulmonary embolism was docu-T

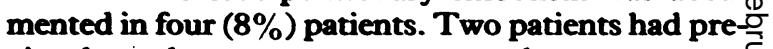
viously undergone coronary artery bypass surgery, and a further two patients had had peripheral vascular surgery.

\section{Symptoms and physical signs}

All 50 patients complained of dyspnoea and/or fatigue on exertion. Forty ( $80 \%$ ) patients had angina pectoris and seven (14\%) patients had intermittent claudication. Sinus rhythm was present in $45(90 \%)$ patients and atrial fibrillation was present in the remaining five $(10 \%)$ patients.

An added heart sound, either third, fourth or both, was present in $35(70 \%)$ patients. A murmur charac-o teristic of mild mitral regurgitation was present in 15 (30\%) patients. Auscultation of the chest was clear in $25(50 \%)$ patients and revealed basal rales in $21 \%$ (42\%) patients and rales halfway up both lung fields in two (4\%) patients. Peripheral oedema confined tơ the ankle area was present in five $(10 \%)$ patients.

\section{Other characteristics}

Forty seven ( $94 \%$ ) patients smoked cigarettes or were recent ex-smokers; only four $(8 \%)$ patients were obese ( $>120 \%$ of desirable body weight).

\section{Existing medication}

Digitalis preparations were being taken by $44(88 \%){ }_{\sigma}^{\omega}$ patients: 37 patients were taking digoxin (mean (SD) daily dose $0.23(0.05) \mathrm{mg}$ ) and seven patients were taking medigoxin (mean daily dose $0.17(0.08) \mathrm{mg}) ., \frac{N}{.}$ Diuretics were being taken by all 50 patients: $47_{0}$ patients were taking frusemide (mean daily dose $121^{\circ}$ (139) $\mathrm{mg}$, range 40-1000 mg) and three were taking bumetanide (mean daily dose $1.5(0.5) \mathrm{mg}$ ). An addi $-\overrightarrow{\mathrm{D}}$ tional potassium sparing diuretic was being takenf by $28(56 \%)$ patients: 25 patients were taking 
spironolactone (mean (SD) daily dose 106 (33) mg) and three patients were taking amiloride $10 \mathrm{mg}$ daily. All 50 patients were normokalaemic (serum potassium $3.4-5.3 \mathrm{mmol} / \mathrm{l}$ ) at the time of assessment. Vasodilator drugs were being taken by $28(56 \%)$ patients: $21(42 \%)$ patients were on isosorbide dinitrate (mean (SD) daily dose 46 (33) $\mathrm{mg}$, range $20-90 \mathrm{mg}$ ). Eleven patients were taking other drugs with vasodilator activity; in eight patients it was a calcium antagonist (either nifedipine or verapamil); four of these patients were also taking nitrates. The remaining three patients were taking hydralazine (two patients) or prazosin (one patient).

Two patients were on antiarrhythmic drugs (amiodarone $200 \mathrm{mg}$ daily). Other drugs included warfarin, six patients; oral hypoglycaemic drugs, four patients; thyroxine, one patient; and insulin, one patient.

\section{Functional classification}

The New York Heart Association functional classification based on symptoms was: class II, three patients (three male, 0 female); class III, 37 patients ( 30 male, seven female); class IV, 10 patients (seven male, three female).

ASSESSMENT OF LEFT VENTRICULAR FUNCTION AND OTHER INVESTIGATIONS

Electrocardiogram

The standard 12 lead electrocardiogram was normal in only three patients. An old anterior myocardial infarction was the commonest abnormality, occurring in $37(74 \%)$ patients; in 12 of these patients there was also evidence of old inferior myocardial infarction. Two patients had evidence of old inferior myocardial infarction alone. The remaining eight patients had one of a variety of abnormalities: complete left bundle branch block, left ventricular hypertrophy, $T$ wave inversion, and atrial fibrillation.

\section{Chest $x$ ray}

The cardiothoracic ratio was increased $(\geqslant 0.50)$ in 45 $(90 \%)$ patients. The mean (SD) cardiothoracic ratio was $0.55(0.06)$. Twelve patients $(24 \%)$ had normal lung fields, with the remaining $38(76 \%)$ patients having evidence of passive pulmonary congestion of a mild to moderate degree. No patient had frank pulmonary oedema at the time of assessment.

\section{Left ventricular function}

The left ventricular ejection fraction was measured in $46(92 \%)$ patients. Cineangiography was performed in 41 patients and equlibrium radionuclide angiography (with in vivo labelling of the patient's own red blood cells with technetium-99m) in 23 patients. The four patients who did not have the left ventricular ejection fraction measured all had $M$ mode echocardiography performed; the left ventricular and diastolic diameter was $>6.0 \mathrm{~cm}$ in all four patients and the mean (SD) fractional shortening was $0.019(0.08)$. The mean (SD) cineangiographic left ventricular ejection fraction was $0.28(0.14)$ and the mean (SD) radionuclide left ventricular ejection fraction was $0.26(0.09)$. Echocardiographic fractional shortening was measured in 43 patients (mean (SD) $0.18(0.07)$. Pulmonary capillary wedge pressure was measured in $\mathbf{4 0}$ patients (mean (SD) 21.3 (7.8) $\mathrm{mm} \mathrm{Hg}$.

\section{Exercise capacity}

Maximum exercise capacity was measured in 29 patients. A bicycle ergometer was used with a protocol which began at a workload of $20 \mathrm{~W}$ for two minutes and increased by $10 \mathrm{~W}$ per minute thereafter. The mean (SD) maximum workload achieved was $76.0(25 \cdot 7) \mathrm{W}$.

\section{Ambulatory electrocardiogram}

Ambulatory 24 hour electrocardiograph recording was performed in $27(54 \%)$ patients. There was no selection process. The mean left ventricular ejection fraction in these patients was 0.26 -that is, the same as in the group overall. The severity of ventricular arrhythmias was scored by the Lown classification. ${ }^{14}$ All patients had evidence of ventricular arrhythmias. The classification of patients was as follows: grade $\mathbf{0 \text { , }}$ no patients; grade 1, 10 patients; grade 2, seven patients; grade 3, one patient; grade $4 A$, two patients; grade $4 \mathrm{~B}$, five patients; and grade 5 , two patients.

\section{FOLLOW UP DETAILS}

\section{Status: dead or alive}

Twenty six $(52 \%)$ patients died during follow up. The mean (SD) follow up from assessment was $17 \cdot 7$ (10.8) months; follow up for those who died was 11.3 $(10 \cdot 2)$ months and for survivors it was $24 \cdot 7(6 \cdot 3)$ months. Figures 1 and 2 show life table analyses from assessment and from onset of left ventricular failure. Death was sudden in $\mathbf{1 7}$ patients and due to progressive cardiac failure in nine patients. No deaths were attributable to non-cardiac causes.

Tables 1, 2, and 3 show the demographic and clinical details, treatment, and assessment of cardiac function in survivors and patients who died. Death within one year was most likely to occur in those patients with the lowest left ventricular ejection fraction, the highest Lown grade for 24 hour ambulatory electrocardiographic recording, in the presence of a gallop rhythm, and in those classified as New York Heart Association functional class IV. Death within 


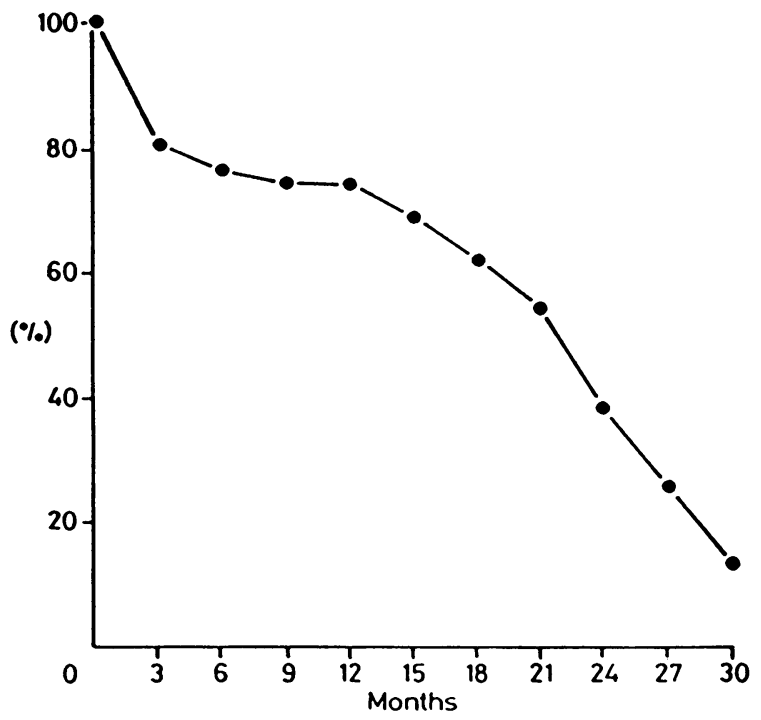

Fig 1 Life table analysis: from assessment of left ventricular failure.

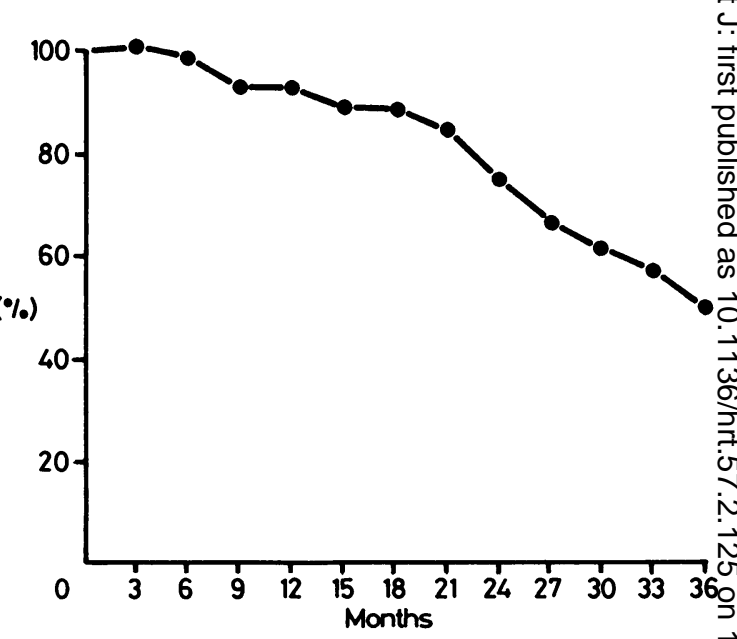

Fig 2 Life table analysis: from onset of left ventricular failure.

two years was predicted by left ventricular ejection fraction, Lown grade, and pulmonary capillary응 wedge pressure.

None of the other variables influenced survival Table 4 shows a comparison of sudden and non-

Table 1 Survivors versus deaths at one and two years' follow up: clinical details

\begin{tabular}{|c|c|c|c|c|c|c|}
\hline & \multicolumn{2}{|c|}{ By 12 months } & \multirow[b]{2}{*}{ Significance } & \multicolumn{2}{|c|}{ By 24 months } & \multirow[b]{2}{*}{ Significance } \\
\hline & $\begin{array}{l}\text { Survivors } \\
(n=37)\end{array}$ & $\begin{array}{l}\text { Deaths } \\
(n=13)\end{array}$ & & $\begin{array}{l}\text { Survivors } \\
(n=15)\end{array}$ & $\begin{array}{l}\text { Deaths } \\
(n=24)\end{array}$ & \\
\hline $\begin{array}{l}\text { Age (years) (mean (SD)) } \\
\text { Sex (male:female) } \\
\text { Duration of LVF (months) (mean (SD)) } \\
\text { NYHA class: }\end{array}$ & $\begin{array}{l}56 \cdot 8(6 \cdot 95) \\
28: 9 \\
17 \cdot 1(14 \cdot 62)\end{array}$ & $\begin{array}{l}57 \cdot 2(6 \cdot 13) \\
12: 1 \\
15 \cdot 5(10 \cdot 78)\end{array}$ & $\begin{array}{l}\text { NS } \\
\text { NS } \\
\text { NS }\end{array}$ & $\begin{array}{l}54 \cdot 7(7 \cdot 60) \\
10: 5 \\
21 \cdot 7(14 \cdot 22)\end{array}$ & $\begin{array}{l}57 \cdot 8(6 \cdot 01) \\
22: 2 \\
14 \cdot 2(9 \cdot 80)\end{array}$ & $\begin{array}{l}\text { NS } \\
\text { p }<0.05 \\
\text { NS }\end{array}$ \\
\hline II & $\begin{array}{r}3 \\
30 \\
4\end{array}$ & $\begin{array}{l}0 \\
7 \\
6\end{array}$ & $p<0.01$ & $\begin{array}{r}1 \\
13 \\
1\end{array}$ & $\begin{array}{r}2 \\
15 \\
7\end{array}$ & NS \\
\hline $\begin{array}{l}\text { Gallop rhythm (\%) } \\
\text { Mitral regurgitation (\%) } \\
\text { Previous MIs: }\end{array}$ & $\begin{array}{l}23(62 \%) \\
12(23 \%)\end{array}$ & $\begin{array}{c}12(92 \%) \\
3(23 \%)\end{array}$ & $\mathrm{p}_{\mathrm{N} S}<0.05$ & $\begin{array}{c}10(67 \%) \\
4(27 \%)\end{array}$ & $\begin{array}{c}16(67 \%) \\
7(29 \%)\end{array}$ & $\begin{array}{l}\text { NS } \\
\text { NS }\end{array}$ \\
\hline $\begin{array}{c}0 \\
1 \\
2 \\
>2\end{array}$ & $\begin{array}{r}4 \\
16 \\
11 \\
6\end{array}$ & $\begin{array}{l}3 \\
5 \\
2 \\
3\end{array}$ & NS & $\begin{array}{l}0 \\
8 \\
6 \\
1\end{array}$ & $\begin{array}{l}3 \\
9 \\
4 \\
7\end{array}$ & NS \\
\hline
\end{tabular}

LVF, left ventricular function, NYHA, New York Heart Association; MIs, myocardial infarctions.

Table 2 Survivors versus deaths at one and two years' follow up: medication

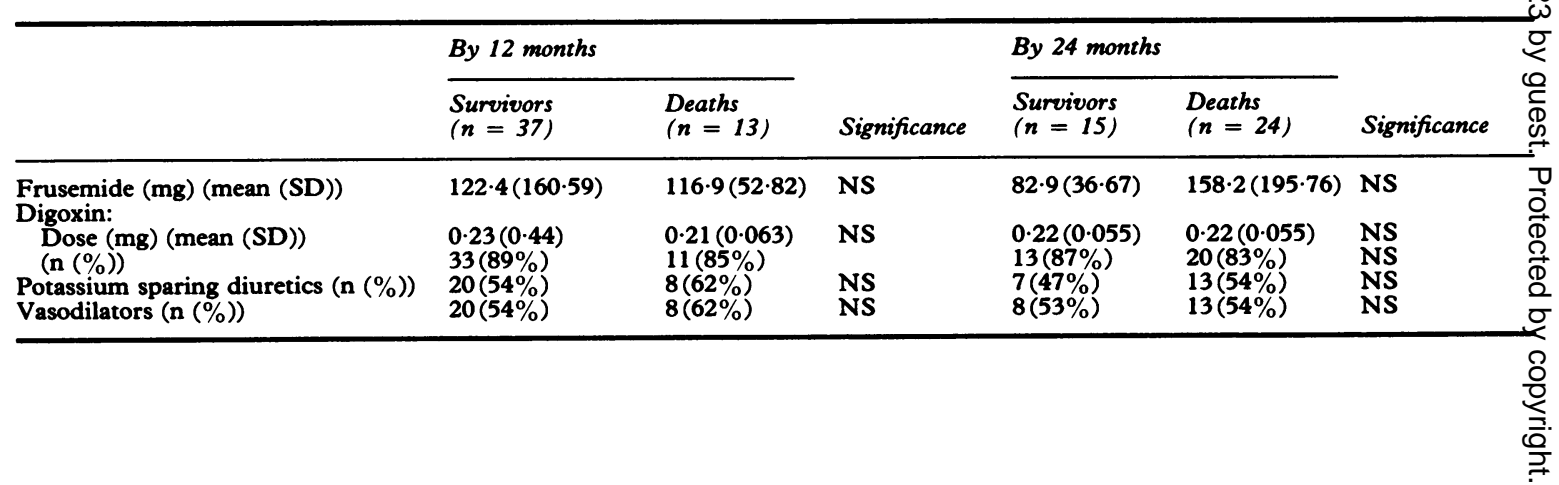


Table 3 Survivors versus deaths at one and two years' follow up: cardiac assessment

\begin{tabular}{|c|c|c|c|c|c|c|}
\hline \multirow[b]{2}{*}{ eariable } & \multicolumn{2}{|l|}{ By 12 months } & \multirow[b]{2}{*}{ Significance } & \multicolumn{2}{|l|}{ By 24 months } & \multirow[b]{2}{*}{ Significance } \\
\hline & $\begin{array}{l}\text { Survivors } \\
(n=37)\end{array}$ & $\begin{array}{l}\text { Deaths } \\
(n=13)\end{array}$ & & $\begin{array}{l}\text { Survivors } \\
(n=15)\end{array}$ & $\begin{array}{l}\text { Deaths } \\
(n=24)\end{array}$ & \\
\hline $\begin{array}{l}\text { CWP (mm Hg) (n) } \\
\text { V cine EF (mean (SD)) (n) } \\
\text { NLVEF (mean (SD) (n) } \\
\text { ardiothoracic ratio (mean (SD) (n) } \\
\text { cho FS (mean (SD)) (n) }\end{array}$ & $\begin{array}{l}20.9(7.72)(31) \\
0.31(0.134)(31) \\
0.26(0.073)(20) \\
0.54(0.061)(37) \\
0.19(0.068)(34)\end{array}$ & $\begin{array}{l}24.0(8.60)(10) \\
0.18(0.087)(10) \\
0.22(0.113)(3) \\
0.57(0.046)(13) \\
0.14(0.071)(9)\end{array}$ & $\begin{array}{l}\text { NS } \\
\text { p< }<0.01 \\
\text { NS } \\
\text { NS } \\
\text { NS }\end{array}$ & $\begin{array}{l}18.0(7.04)(11) \\
0.41(0.108)(11) \\
0.29(0.081)(9) \\
0.55(0.078)(15) \\
0.19(0.081)(15)\end{array}$ & $\begin{array}{l}24.3(8.23)(19) \\
0.22(0.086)(7) \\
0.22(0.086)(7) \\
0.56(0.045)(24) \\
0.16(0.064)(18)\end{array}$ & $\begin{array}{l}p<0.05 \\
p<0.001 \\
\text { NS } \\
\text { NS } \\
\text { NS }\end{array}$ \\
\hline $\begin{array}{l}1 \\
2 \\
3 \\
4 \mathrm{~A} \\
4 \mathrm{~B} \\
5 \\
\text { exercise capacity (W) (mean (SD)) (n) }\end{array}$ & $\begin{array}{l}9 \\
7 \\
0 \\
1 \\
2 \\
2 \\
78 \cdot 8(25 \cdot 22)(25)\end{array}$ & $\begin{array}{l}1 \\
0 \\
1 \\
1 \\
3 \\
0 \\
62 \cdot 0(25 \cdot 88)(5)\end{array}$ & $p<0.02$ & $\begin{array}{l}7 \\
7 \\
0 \\
0 \\
1 \\
1 \\
80 \cdot 0(76 \cdot 46)(9)\end{array}$ & 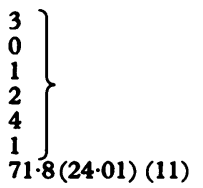 & $p<0.02$ \\
\hline
\end{tabular}

CWP, pulmonary capillary wedge pressure; LV cine EF, left ventricular ejection fraction measured by cineangiography; RNLVEF, radionuclide left entricular ejection fraction; Echo FS, fractional shortening measured by echocardiography.

Table 4 Sudden versus non-sudden deaths

\begin{tabular}{|c|c|c|c|}
\hline Variable & Sudden deaths $(n=17)$ & Non-sudden deaths $(n=9)$ & Significance \\
\hline $\begin{array}{l}\text { Age (years) } \\
\text { Sex (M:F) } \\
\text { Duration of left ventricular failure (mnth) } \\
\text { Previous MIs } \\
\text { Gallop rhythm } \\
\text { Mitral regurgitation (n) } \\
\text { NYHA class (n) II } \\
\end{array}$ & $\begin{array}{l}56 \cdot 6(7 \cdot 0) \\
17: 0 \\
13 \cdot 2(8 \cdot 7)(17) \\
1 \cdot 71(1 \cdot 53(17) \\
9 \\
5 \\
2 \\
12 \\
3\end{array}$ & $\begin{array}{l}58 \cdot 8(7 \cdot 3) \\
7: 2 \\
19 \cdot 4(15 \cdot 4)(9) \\
1 \cdot 56(1 \cdot 01)(19) \\
8 \\
3 \\
0 \\
5 \\
4\end{array}$ & $\begin{array}{l}\text { NS } \\
\text { NS } \\
\text { NS } \\
\text { NS } \\
\text { NS } \\
\text { NS } \\
\text { NS }\end{array}$ \\
\hline $\begin{array}{l}\text { Medication: } \\
\text { Frusemide (mg) (mean (SD)) } \\
\text { Digoxin (n) } \\
\text { K supplements (n) } \\
\text { Vasodilators (n) } \\
\text { Pulmonary capillary wedge pressure (mm Hg) } \\
\text { LV cine EF (mean (SD)) (n) } \\
\text { RNLVEF } \\
\text { Lown grade } \\
\text { Cardiothoracic ratio } \\
\text { Echo fractional shortening } \\
\text { Maximum exercise capacity (W) }\end{array}$ & $\begin{array}{l}155(228) \\
14 \\
9 \\
8 \\
23 \cdot 3(7 \cdot 1)(13) \\
21 \cdot 9(7 \cdot 6)(13) \\
23 \cdot 0(9 \cdot 4)(4) \\
3 \cdot 36(1 \cdot 63)(7) \\
0.56(0.04)(17) \\
0 \cdot 15(0.06)(13) \\
81 \cdot 4(21 \cdot 2)(7)\end{array}$ & $\begin{array}{l}154(67) \\
7 \\
5 \\
6 \\
25 \cdot 0(10.5)(7) \\
16 \cdot 9(8 \cdot 7)(6) \\
20.7(9 \cdot 1)(3) \\
3 \cdot 38(1 \cdot 80)(4) \\
0.57(0.05)(9) \\
0 \cdot 16(0.07)(7) \\
55.0(20 \cdot 8)(4)\end{array}$ & $\begin{array}{l}\text { NS } \\
\text { NS } \\
\text { NS } \\
\text { NS } \\
\text { NS } \\
\text { NS } \\
\text { NS } \\
\text { NS } \\
\text { NS } \\
\text { NS } \\
\text { NS }\end{array}$ \\
\hline
\end{tabular}

Results are expressed as mean (SD) (n).

RNLVEF, radionuclide left ventricular ejection fraction; ECG, 12 lead electrocardiogram; LV cine EF, left ventricular ejection fraction.

sudden deaths. No differences were detected for any of the recorded variables between sudden and nonsudden deaths.

\section{Alteration in treatment and surgical referral}

After the initial assessments only three $(6 \%)$ patients continued on unchanged medication because this was judged to be optimal. Five $(10 \%)$ patients died before any necessary alterations in treatment could be effected. Twenty two (44\%) patients entered a six month trial of oral prenalterol versus placebo ${ }^{15}$; 11 patients received prenalterol. Prenalterol treatment did not influence survival favourably or unfavourably. Five patients had the dose of diuretic increased or a potassium sparing diuretic was added; and nine patients had long acting nitrate drugs added (seven patients) or increased (two patients). Two patients were started on an antiarrhythmic drug, amiodarone. The remaining four patients were referred for cardiac surgery, with subsequent alteration in their drug treatment.

\section{Functional status of survivors}

Figure 3 shows the New York Heart Association functional status of survivors. Only seven had a lasting improvement (longer than 12 months) in functional class.

This was attributed to cardiac surgery in two patients and to changes in medical treatment in the remaining five patients (prenalterol three patients, nitrates one patient, and increased diuretics one patient). 


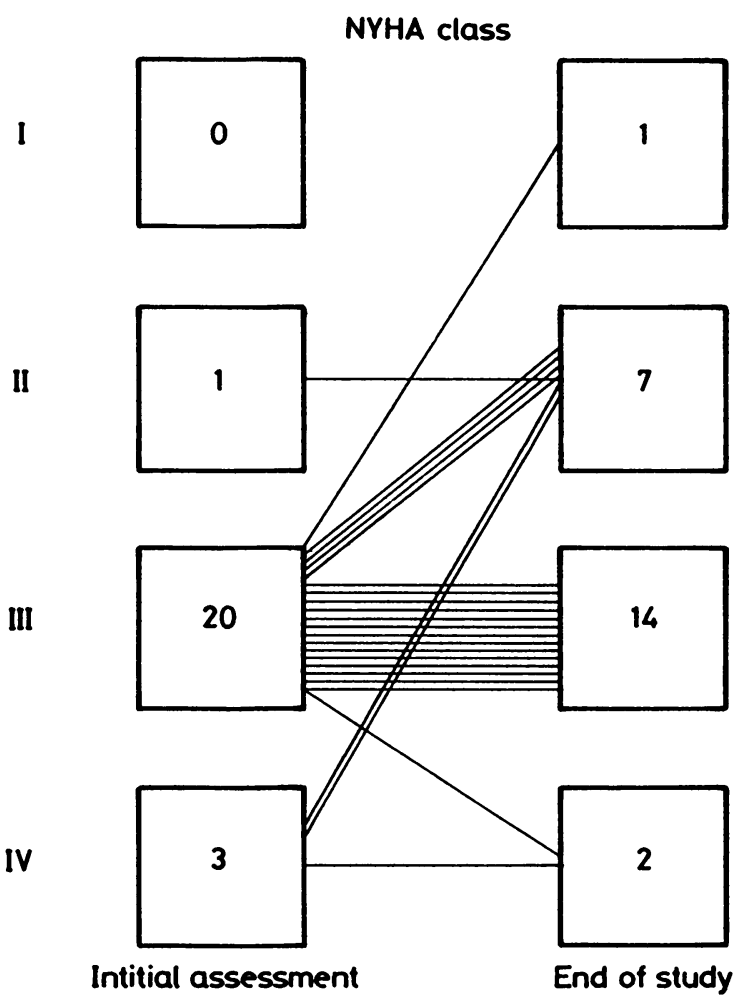

Fig 3 Functional status of survivors. NYHA, New York Heart Association.

\section{Discussion}

The fifty patients who we studied had severe refractory cardiac failure. Their medication at the time of assessment was already comprehensive, with over half of the patients taking drugs with vasodilator activity or "third line" drugs. Nitrates tended to be the most popular, because of their effect in both lowering left ventricular filling pressure and providing prophylaxis against attacks of angina pectoris. The majority of patients had triple vessel coronary artery disease and had had one or more myocardial infarctions and their left ventricular function was very poor. It is therefore not surprising that the mortality was so high and the outcome so poor. Our findings accord with those of many published series. ${ }^{1-3}$ We confirmed that those patients with lowest left ventricular ejection fraction are more likely to die. ${ }^{16} \mathrm{We}$ also confirmed that those patients with the most serious ventricular arrhythmias on an ambulatory electrocardiogram have the worst prognosis. ${ }^{51718}$ There appears to be an inverse relation between left ventricular ejection fraction and Lown grade (fig 4); few deaths occurred among patients

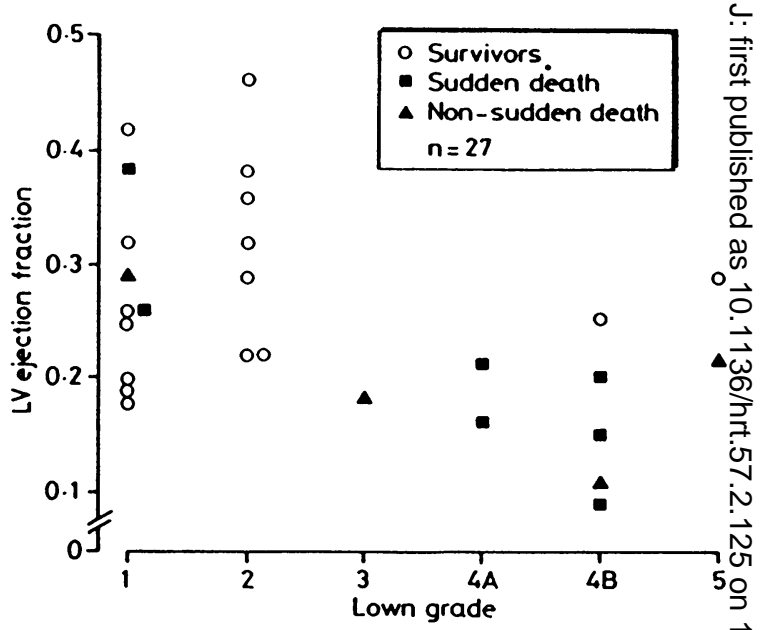

Fig 4 Left ventricular ( $L V$ ) ejection fraction versus Lown grade in 27 patients with chronic ischaemic cardiac failure.

with a left ventricular ejection fraction $>0.30$ ando the lesser ventricular arrhythmias, whereas mortality was highest in patients with a combination of a veryo low left ventricular ejection fraction and serious ventricular arrhythmia. Sudden deaths and non-sudden deaths are equally common in this higher risk group Severe ventricular arrhythmias thus appear to be aD marker for severe left ventricular damage.

Current therapeutic practice concentrates on improving the symptoms and status of the left ventricular failure. Our study indicates that some atten $-\frac{\vec{F}}{\overline{0}}$ tion should also be paid to these arrhythmias. A similar view has been expressed by Wilson. ${ }^{13}$ Con-D ventional antiarrhythmic drugs are, however, often difficult to use in this category of patients because of a deleterious effect on left ventricular function ${ }^{19}$ or non-responsiveness to treatment. ${ }^{20}$

The challenge of preventing sudden death in patients with congestive heart failure has recentlys been reviewed by Packer. ${ }^{21}$ Our study was not designed to test the effect of such an intervention.

Treatment was adjusted on an individual basis $N_{0}$ We treated only four patients with antiarrhythmic drugs; in every case amiodarone was our choice because it is the least likely of the drugs currentlye available to depress left ventricular function and its? additional antianginal effect may also be beneficial tof this class of patient. ${ }^{22} 23 \mathrm{~A}$ recent report by Cleland et al suggested that amiodarone can successfully sup? press ventricular arrhythmias in patients with severe heart failure ${ }^{24}$; however, in this small three month study the impact on survival could not be fully? assessed, but it is noteworthy that three patients died? suddenly on placebo whereas there were no sudder? 
deaths on amiodarone. Among our four patients, one sudden death occurred in a patient taking amiodarone and the three remaining patients survived.

Sudden death was almost twice as common as death from progressive cardiac failure in our series. This proportion is higher than in the other published series. ${ }^{3-5}$ The explanation may lie in the definition of "sudden death" and the selection of patients, although we cannot exclude the possibility that our treatment may have influenced this observation. Short term treatment with prenalterol may cause ventricular arrhythmia when given to susceptible patients, ${ }^{25}$ but long term treatment is not associated with increased arrhythmia or mortality; indeed the degree of $\beta$ blockade perhaps might be useful in preventing arrhythmias. ${ }^{15}$ Thirty nine patients were taking digoxin and were in sinus rhythm. Five of the six patients not prescribed digoxin died. There is still controversy about whether long term digoxin treatment provides worthwhile benefits in such patients. ${ }^{26-28}$ We did not observe any digoxin toxicity in these patients during follow up and we attribute this to the fact that all these patients were already stabilised on digoxin at the time of assessment. Serum potassium was measured periodically in most patients. No episodes of severe hypokalaemia (serum potassium $<3.0 \mathrm{mmol} / \mathrm{l}$ ) occurred during follow up despite the large doses of frusemide used.

Cardiac surgery, namely resection of a left ventricular aneursym, with or without coronary artery bypass surgery, was only considered suitable for four of the patients. Two further patients had had previous cardiac surgery: one a resection of a left ventricular aneurysm with coronary artery bypass and one a coronary artery bypass alone. The remaining patients were not offered surgery-almost invariably because they had severely reduced left ventricular function without discrete aneurysm. No patient in this series was considered seriously for transplantation; the main reason was that only seven patients were aged $<50$ years.

Evidence is now accumulating that patients such as ours may have an improved prognosis if coronary revascularisation is performed, ${ }^{29-31}$ although the operative and perioperative risks are greater in this group. ${ }^{3132}$ This gradual change in attitudes may mean that a series of patients reported in 10 years time will contain a greater proportion of patients treated surgically.

How then can the outlook be improved for these patients? Undoubtedly optimisation of medical treatment is desirable, and, whenever patients are suitable, cardiac surgery should be carefully considered. Antiarrhythmic drugs should probably be considered although patient selection is difficult. Newer drugs for cardiac failure will continue to attract attention and deserve to be tested in such patients because their prognosis is so poor. Angiotension converting enzyme inhibitors produce clinical benefit ${ }^{33-35}$ and there is some evidence to suggest that they reduce arrhythmias ${ }^{36} 37$ and may improve the prognosis. ${ }^{343538}$ Combined vasodilator treatment with hydralazine and nitrates may also be beneficial. ${ }^{39}$ Larger studies are needed to confirm these promising results.

Despite surgery and intensive drug treatment the damage to the left ventricle may be so great that little improvement can be expected whatever therapeutic manoeuvre is attempted. Cardiac transplantation may then be considered for suitable subjects. Predictably the major risk factors for coronary artery disease noted were cigarette smoking $(94 \%)$ and preceding hypertension $(22 \%)$.

We thank Mr T J Stallard for statistical advice and analysis, and Mrs Jayne Tuckey for assistance in preparing the paper.

\section{References}

1 Bruschke AVG, Proudfit WL, Sones FM. Progress study of 590 consecutive non surgical cases of coronary disease followed 5-9 years. II Ventriculographic and other correlations. Circulation 1973;47:1154-63.

2 Burggraf GW, Parker JO. Prognosis in coronary artery disease. Angiographic haemodynamic and clinical factors. Circulation 1975;51:146-56.

3 Franciosa JA, Wilen M, Ziesche S, Cohn JN. Survival in men with severe chronic left ventricular failure due to either coronary heart disease or idiopathic dilated cardiomyopathy. Am F Cardiol 1983;5:831-6.

4 Massie B, Ports T, Chatterjee $\mathrm{K}$, et al. Long-term vasodilator therapy for heart failure: clinical response and its relationship to haemodynamic measurements. Circulation 1981;63:269-78.

5 Wilson JR, Schwartz JS, St John Sutton M, et al. Prognosis in severe heart failure: relation to haemodynamic measurements and ventricular ectopic activity. F Am Coll Cardiol 1983;2:403-10.

6 Cohn JN, Levine TB, Olivari MT, et al. Plasma norepinephrine as a guide to prognosis in patients with congestive heart failure. N Engl f Med 1984; 311:819-23.

7 McKee PA, Castelli WP, McNamara PM, Kannel WB. The natural history of congestive heart failure: the Framingham study. $N$ Engl $f$ Med 1971;285:1441-6.

8 Cohn JN, Franciosa JA. Vasodilator therapy of cardiac failure. N Engl f Med 1977;297:27-31.

9 Chatterjee K, Parmley WW. Vasodilator therapy for chronic heart failure. Annu Rev Pharmacol Toxicol 1980;20:475-512.

10 LeJemtel TH, Keung E, Sonnenblick EH. Amrinone: a new non-glycosidic non-adrenergic cardiotonic agent effective in the treatment of intractable myo- 
cardial failure in man. Circulation 1979;59: 1098-104.

11 Anonymous. Sympathomimetics in heart failure. Drug Ther Bull 1982;20:77-8.

12 Anonymous. Beta agonists and heart failure. Lancet 1983;ii: $1063-4$.

13 Wilson JR. How and when patients with congestive heart failure die. Int $\mathcal{F}$ Cardiol 1984;6:255-8.

14 Lown B, Wolf $M$. Approaches to sudden death from coronary heart disease. Circulation 1971;44:130-42.

15 Glover DR, Wathen CG, Murray RG, Petch MC, Muir AL, Littler WA. Are the clinical benefits of prenalterol in ischaemic heart failure due to beta blockade?: a six month randomised double blind comparison with placebo. $\mathrm{Br}$ Heart $\mathcal{f}$ 1985;53: 208-15.

16 Mock MB, Ringquist I, Fisher LD, et al. Survival of medically treated patients in the coronary artery surgery study (CASS) registry. Circulation 1982;66: 562-8.

17 Follansbee WP, Michelson EL, Morganroth J. Non sustained ventricular tachycardia in ambulatory patients: characteristics and association with sudden cardiac death. Ann Intern Med 1980;92:741-7.

18 Holmes J, Kubo SH, Cody RJ, Kligfield P. Arrhythmias in ischaemic and non-ischaemic dilated cardiomyopathy: prediction of mortality by ambulatory electrocardiography. Am $\mathcal{F}$ Cardiol 1985;55:146-51.

19 Hillis WS, Whiting B. Antiarrhythmic drugs. Br Med f 1983;286:1332-6.

20 Poll DS, Marchlinski FE, Buxton AE, Doherty JV, Waxman HL, Josephson ME. Sustained ventricular tachycardia in patients with idiopathic dilated cardiomyopathy-electrophysiologic testing and lack of response to antiarrhythmic drug therapy. Circulation 1984;70:451-6.

21 Packer M. Sudden unexpected death in patients with congestive heart failure: a second frontier. Circulation 1985;72:681-5.

22 Marcus FI, Fontaine GH, Frank R, Grosgogeat Y. Clinical pharmacology and therapeutic applications of the antiarrhythmic agent, amiodarone. Am Heart $\mathcal{F}$ 1981;101:480-93.

23 Nademanee K, Hendrickson JA, Peterson B, Cannon $D$, Hecht $H$, Singh BN. Amiodarone: possibly an ideal antiarrhythmic agent [Abstract]. Am $\mathcal{F}$ Cardiol 1982;49:981.

24 Cleland J, Dargie HJ, Findlay I, Wilson J. Effect of amiodarone on arrhythmia and left ventricular function in heart failure [Abstract]. $\mathrm{Br}$ Heart $\mathcal{f}$ 1985;54:647.

25 Capucci A, Fragetti L, Melandri G, Magnani B.
Electrophysiological properties of prenalterol. Inc. f Cardiol 1983;2:391-400.

26 Selzer A. Digitalis in heart failure. Do benefits justiff2 risks? Arch Intern Med 1981;141:18-9.

27 Johnston GD, McDeveitt DG. Is maintenance digoxi necessary in patients with sinus rhythm? Lances 1979;i:657-70.

28 Petch MC. Digoxin for heart failure in sinus rhythm Thorax 1979;3:147-9.

29 Detre K, Peduzzi P, Murphy M, et al. Effect of bypaseे surgery on survival in low and high risk subgroups delineated by the use of simple clinical variables. Cir $\vec{\omega}$ culation 1981;63:1329-38.

30 Mathur VS, Hall RJ, Garcia E, de Castro CM, Coole $\frac{\overrightarrow{7}}{\not}$ DA. Prolonging life with coronary bypass surgery in patients with three-vessel disease. Circulation 1980;62 (suppl 1):90-7.

31 Isom OW, Spencer FC, Glassman E, Denbrown JM Pasternack BS. Long term survival following coroe nary bypass surgery in patients with significant impairement of left ventricular function. Circulation 1975;51 (suppl 1):141-7.

32 Kennedy JW, Kaiser GC, Fisher LD, et al. Clinical an angiographic predictors of operative mortality fronf the collaborative study of coronary artery surgery (CASS). Circulation 1981;63:793-802.

33 Dzau VJ, Colucci WS, Williams GH, Curfman GN Meggs L, Hollenberg NK. Sustained effectiveness of converting-enzyme inhibition in patients with severe congestive heart failure. $N$ Engl $f$ Med 1980;302 1373-9.

34 Captopril Multicenter Research Group. A placeboฏ controlled trial of captopril in refractory chroni® congestive heart failure. $\mathcal{F} \mathrm{Am}$ Coll Cardiol 1983 2:755-63.

35 Sharpe DN, Murphy J, Coxon R, Hannan SF Enalapril in patients with chronic heart failure: placebo-controlled, randomised, double-blind study. Circulation 1984;70:271-7.

36 Cleland JGF, Dargie HJ, Ball SG, et al. Effects of enalapril in heart failure: double blind study of effects on exercise performance, renal function, hormones? and metabolic state. Br Heart $\mathcal{f}$ 1985;54:305-12.

37 Cleland JGF, Dargie HJ, Hodsman GP, et al. Captoprif in heart failure: a double blind controlled trial. $B \widehat{b}$ Heart $\mathcal{F} 1984 ; 52: 530-5$.

38 Furberg C. Yusuf S. Effect of vasodilators on surviva in chronic congestive heart failure. Am $\mathcal{f}$ Cardia黑. 1985;55:1110-3.

39 Cohn JN, Archibald DG, Ziesche S, et al. Effect of vasodilator therapy on mortality in chronic conges tive heart failure. $N$ Engl f Med 1986;314:1547-52 